\title{
Domains of Political Metaphors in Presidential Speeches
}

\author{
Truly Almendo Pasaribu \\ Sanata Dharma University \\ tr.almendo@gmail.com
}

\begin{abstract}
Speeches are products of human minds reflecting ideas and opinions of the speakers. Crystal (1987) mentions that the way people use language does not only give us information about their geographical, ethnic and social background, but it also reflects the type of context in which they are communicating. As an interesting feature of a language, metaphors in political speeches can be powerful and persuasive. This research aimed at finding the source domains of political metaphors in Joko Widodo's speeches, namely: his victory speech and his inaugural speech. These speeches were chosen to be analyzed due to their distinct context and setting. To achieve the goal of the study, the paper explicated Lakoff and Johnson's Contemporary Theory of Conceptual Metaphor (1980, 1992). The findings and discussion argue that the speeches use more positive metaphors of "unity" rather than metaphors of "battle or competition". Furthermore, the texts also conceptualize Indonesian political realm as a journey and navigation, which give the audience a sense of progress. The maritime metaphors in particular are abundant in the two speeches because they reflect one of Widodo's visions to strengthen Indonesian maritime.
\end{abstract}

Keywords: political metaphors, speeches, conceptual metaphors

\section{Introduction}

Speeches reflect how creative human minds can be in expressing ideas, intention and thoughts. A speech can be entertaining and also politically powerful. Many leaders realize the importance of public speeches as they serve as a tool of their political legitimization. Crystal (1987) mentions that the way people use language gives us information about their physical type, their geographical, ethnic and social background, and the type of context in which they are communicating. Similarly, the way political leaders use a language reflects their thoughts and intention.
Those who are involved in a political domain use various strategies to win audience; one of them is by using metaphors (Widiana \& Yustisiana, 2015). Widiana \& Yustiana(2015) analyzed political metaphors in mass media and argued that this linguistic feature highly affected the public. In investigating metaphors found in Widodo's speeches, this study employed Lakoff's Contemporary Theory of Metaphor (1992). According to Lakoff (1992) metaphors are not mere words or expression, but they reflect mapping across conceptual domains, from the source domains to the target domains. In other words, a metaphor consists of a source 
domain and a target domain. Many concepts that we use in everyday activities are abstract concepts like time, emotions, communication, minds, and ideas, which are usually described metaphorically in more concrete concepts like human body, food, objects, etc.

The use of metaphors tells a lot about how we perceive things. Wahab (1991) argued that the metaphors in written texts were influenced by the writers' environment and surroundings. Lakoff and Johnson (1980) also argued that metaphors served as a means that structured how we perceive, think and do. It is not unusual for us to use more concrete experience in our lives to describe more abstract concepts. Some layers of politics are in the abstract realm such as political leaders' visions and missions. Thus, metaphors are widely used in political speech as one strategy to reach wider audience. For example, studies have documented that Obama has exploited metaphors in his speeches (Xu, 2010; Escudero, 2011). Xu (2010) argued that Obama used source domains people could emotionally relate to, which helped him influence his people.

$$
\text { Presidential inaugural }
$$

speeches are important and momentous. An article 'Why Rhetoric?" elaborates that "a political speech can be so powerful in expressing a vision that it is not only a comment on a historical moment, but itself historically momentous." (Why, Online) Furthermore, Wilson (1994) added that the inaugurals are delivered not only to convey presidents' visions and missions, but also to win the heart of his/her citizens. To serve these purposes, the Indonesian President also used metaphors in his victory and inaugural addresses. This study analyzes those metaphors through Lakoff's Contemporary Theory of Metaphor (1992), which is further elaborated under the literature review. Furthermore, after the data were collected and classified, the findings and discussion elaborate the possible conceptual metaphors appeared in Widodo's addresses. Finally, it concludes with major ideas and findings of the research.

\section{Literature Review}

Many studies have documented the use of metaphors in communication (Wahab, 1991; Pasaribu, 2013, Widiana \& Yustisiana, 2015). Wahab (1991) argued that there is a close relation between metaphors and mind. $\mathrm{He}$ found that when writers in his study created metaphors, they are influenced greatly by its environment. As one interesting aspect of language, the use of metaphor gives us information about our geographical, ethnic and social background (Crystal, 1987) Pasaribu (2013) found that metaphors helped Indonesian speakers to express their feeling, particularly "love", using different domains of experience. Metaphors helped people communicate various shades of abstract things, such as emotions. Furthermore, Widiana and Yustisiana (2015) also investigated political metaphos in mass media. They found out that politics was compared with very different entities. Interestingly, they also argued that political 
metaphors were highly persuasive. Although the readers were not really interested in the political news, they understood the message conveye through political metaphors. Both Pasaribu (2013) and Widiana and Yustisiana (2015) analyzed their data by using Contemporary Theory of Conceptual Metaphor (Lakoff and Johnson, 1980; Lakoff, 1992). Although the current study also used the theory of metaphor proposed by Lakoff, the goal of this study aimed at elaborating the source domains of political metaphors in Widodo's victory speech and inaugural speech.

According to Lakoff and Johnson (1980) a metaphor is not merely "a device of poetic imagination or an ornament of language". Metaphors are myriad in everyday communication because when we use them we conceptualize one domain in terms of another. A famous example proposed by Lakoff (1992) is "love is a journey" because of some shared similarities, such as the lovers are travelers who have their destinations in life. The target domain "love" is understood partially in terms of the source domain "journey". Kövecses (2010) adds that a conceptual metaphor consists of two conceptual domains, in which one domain is understood in terms of another. The metaphor "love is a journey" helps us understand a relatively abstract matter, i.e. love, to a more concrete one, i.e. journey. In this example the target domain is the abstract concept "love" and the source domain is the more concrete concept "journey". The explanation and the examples under this literature framework help us analyze the source domains of political metaphors in two Widodo's speeches.

\section{Data Collection}

This study used a qualitativedescriptive research that focused on the description of current language phenomenon. The method was carried out by gathering the data, analyzing the data and presenting the data. This study was interested in two Widodo's speeches, namely: his victory speech and inaugural speech. These speeches were analyzed because they have distinct context and setting. The data was taken from the archive of Jokowi's speeches which were delivered to public and recorded on Youtube Channel. After collecting the data, they were analyzed by finding and labelling the metaphors in Widodo's speeches, interpreting the components through the textual feature, and concluding the findings and discussion.

\section{Findings and Discussion}

Metaphors are pervasively employed in political speeches. Metaphors manipulate verbal messages to trigger our mental image. Escudero (2011: 46) mentions that "the message conveyed by metaphor is doubly powerful as it works through both auditory and visual channels at the same time, a verbal message and a mental image". Based on the classification of the data, the domains of metaphors appearing in Joko Widodo's speeches are discussed in the following part. 


\section{Unity/relationship}

As the title of the section suggests, the theme of unity tries to evoke the feeling of comradeship. When people unite, they tend to develop certain relationships. Indonesian people hold the value of gotong royong, or mutual cooperation, highly. This spirit of mutual cooperation is repeated 6 times in these two presidential speeches. People have to work together, as a team, to get out of the crisis. They have to meet this challenge and address the crisis. Widodo uses this theme in several sentences of his speeches to emphasize unity. The conceptual metaphors under this theme are:

1) Saudara-saudara sebangsa dan setanah air,....

My brothers and sisters,....

2) Pertama-tama, saya mengucapkan terima kasih dan penghargaan tinggi kepada bapak Prabowo Subianto dan bapak Hatta Rajasa yang telah menjadi sahabat dalam kompetisi politik....

First of all, my gratitude and highest appreciation go to Mr. Prabowo Subianto and Mr. Hatta Rajasa who have been our friends in this political competition...

3) ...untuk mendapatkan mandat rakyat untuk memimpin negeri ini lima tahun ke depan.

...in getting the people's mandate to lead this country for the next five years.

4) Saya yakin, Negara ini akan semakin kuat dan berwibawa jika semua lembaga negara bekerja memanggul mandat yang telah diberikan oleh Konstitusi. I believe this country will grow stronger and more dignified if all state institutions carry the mandates given to them by the Constitution.

5) Atas nama rakyat dan pemerintah Indonesia, saya mengucapkan terima kasih dan penghargaan yang sebesar-besarnya kepada Yang Mulia kepala negara dan pemerintahan serta utusan khusus dari negara-negara sahabat .

On behalf of the people and the government of Indonesia, I extend my gratitude and appreciation to their excellencies heads of states and governments and special envoys from foreign nations which have been our friends.

These conceptual metaphors under the theme unity/relationship reflect the context of Asian culture. Eastern societies usually put more importance of collectivity (Wahab, 1991). The metaphors show that the speaker emphasizes on positive relationship between him and the citizens (example 1) as well as between him and his political rivals (example 2). Metaphors (3) and (4) also show that the President is being humble by considering the Indonesian people and the constitution as the parties that he serves. He also emphasizes unity by considering other countries as friends in example (5).

\section{War}

It is not unusual that political leaders use the battle metaphor in conveying their speech. In these speeches, the speaker represents himself as the commander in chief whose duty is to defend (6), protect (7) and lead his army to struggle in the battle (8). 
6) Semangat gotong royong itulah yang akan membuat bangsa Indonesia bukan saja akan sanggup bertahan dalam menghadapi tantangan....

The spirit of gotong royong will not only make Indonesia survive its problems.... 7) Saya yakin, dengan kerja keras dan gotong royong, kita akan akan mampu melindungi segenap bangsa Indonesia dan seluruh tumpah darah Indonesia I believe that with hard work and cooperation, we will be able to protect the nation and all the citizens of Indonesia

8) ...perjuangan mencapai Indonesia yang berdaulat, Indonesia yang berdikari

...the struggle to achieve a sovereign, independent, and characterized Indonesia can only be realized if we work together hand in hand.

9) ...Prabowo Subianto dan bapak Hatta Rajasa yang telah menjadi sahabat dalam kompetisi politik untuk mendapatkan mandat rakyat.

...Mr. Prabowo Subianto and Mr. Hatta Rajasa who have been our friends in this political competition in getting the people's mandate to lead this country for the next five years.

Politics and war are two completely different entities. But in this case, politics is partially understood in terms of war. In example (6), the text shows that Widodo considers the Indonesian citizens as armies when facing challenges. The same concept is used in example (7) and example (8). The expressions from the vocabulary of war are scattered in Widodo's speeches to emphasize the importance of working together to survive (6), protect (7) and struggle (8) for Indonesia. Furthermore, it is also interesting to see that example (9) talks about political election. In this case, the source domain is competition which is used to describe political election. Both share the attributes that there are more than two parties who compete to win the election.

From the examples we see that although politics and war are two distinct concepts, the source domain concepts of war are mapped into the target concept, i.e. politics because they share some similarities. It is also interesting to point out that Widodo used more positive metaphors of "unity" rather than metaphors of "battle or competition". After the celebrating the outcome of 2014 political election, he repeatedly persuaded Indonesian citizens to unite as one nation.

\section{Journey}

By using the journey metaphor, Widodo places the people in a position of being on a journey. When we talk about journey, we have a path, process, movement, and destination. This concept is often used to describe to other concepts, including politics. Journey and politics are exactly two different kinds of thing and involve two different kinds of action. But politics is partially structured, understood and performed in terms of journey as revealed by the these metaphorical linguistic expressions.

10) Pemilihan Umum Presiden telah membawa politik ke sebuah fase baru bukan lagi sebagai sebuah peristiwa politik semata-mata, tetapi peristiwa kebudayaan.

The presidential election has brought politics to a new phase - it wasn't only a political event, but also a cultural event. 
11) Saya berharap, kemenangan rakyat ini akan melapangkan jalan untuk mencapai dan mewujudkan Indonesia yang berdaulat secara politik,

I hope that this victory will open our ways to reach and achieve a politically sovereign.

12) ...bekerja keras mencapai kehendak kita bersama sebagai bangsa yang besar.

...working hard in order to achieve our dream of becoming a big nation.

13) ...bersama-sama melanjutkan ujian sejarah berikutnya yang maha berat, yakni mencapai dan mewujudkan Indonesia

It's time for us to continue with our next historical tasks, which are tremendously heavy; to transform Indonesia into a sovereign country politically

14) ...akan terus menjalankan politik luar negeri bebas-aktif, yang diabdikan untuk kepentingan nasional,

Indonesia - as the world's third-largest democracy, the world's most populous Muslim nation, an archipelagic state and the biggest nation in Southeast Asia will continue to exercise our independent and active foreign policy dedicated for the national interest

Lakoff (1992) analyzed the conceptual metaphors "Love is a Journey" because this conceptual metaphor described one domain of experience, that is love, in terms of a very distinct domain of experience, journeys. Indonesian citizens are described as travelers (example 13 and 14) on a journey of wide roads (11) involving some phases (10) to achieve common goals (example 12) as a nation. From these examples, we can see that we understand politics in terms of a very different entity, journeys. Journey metaphors encourage the audience because the give the sense of progress. Therefore, political leaders use this basic human experience to explain politics, which is an abstract concept.

\section{Human's Character}

According to Lakoff and Johnson (1980), personification is a special type of ontological metaphor where the object is further specified as being a person so that a wide variety of experiences with nonhuman entities can be described in terms of human motivations, characteristics and activities. In Theory of Conceptual Metaphor (1980, 1992), personification is a kind of metaphor because when we use personification, we compare a nonhuman domain in terms of a human domain. This kind of comparison is abundant in daily conversation because we compare something to ourselves as human beings. Some expressions in the speeches also described one domain, i.e. a country, in terms of another domain, i.e. human's character.

15) Indonesia yang berkepribadian, hanya akan dapat tercapai dan terwujud apabila kita bergerak bersama.

characterized Indonesia can only be realized if we work together hand in hand.

16) kita akan akan ... mencerdaskan kehidupan bangsa...

I believe that with hard work and cooperation, we will be able to protect the nation and all the citizens of Indonesia, to improve public welfare, to educate the nation and to participate in efforts to maintain the world order based on independence, eternal peace and social justice. 


\section{7) Indonesia yang... dan berkepribadian dalam kebudayaan}

I hope that this victory will open our ways to reach and achieve a politically sovereign, economically independent, and culturally characterized Indonesia.

The componential features of a country are different from those of human beings. A country is inanimate, but it is understood in terms of a human metaphor. As human we are close to the concept of ourselves. In this case, the text describes a nonhuman domain, a country, in terms of a human domain. It is easier for us to understand the concept of a country when thinking about our being. In other words, it is possible to make people understand other abstract phenomena by explaining them using metaphors related to human beings, such as characteristics and actions.

\section{Navigation}

Maritime is related to human activity at sea (Cambridge Advanced Learners' Dictionary). The activity from one place to another by directing a ship is called navigation. The concept of maritime navigation involves captains, navigators, sailors, ships, waves, currents and destinations. Uniquely, Widodo uses some maritime metaphors in his speech as seen below:

18) jiwa pelaut yang berani mengarungi gelombang dan hempasan ombak yang menggulung.

namely the heart of a sailor who courageously sails through big currents and rolling waves.

19) Sebagai nahkoda yang dipercaya oleh rakyat, saya mengajak semua warga bangsa untuk naik ke atas kapal Republik Indonesia dan berlayar bersama menuju Indonesia Raya.

As a captain mandated by the people, I'm asking the entire nation to board this ship that is the Republic of Indonesia and to sail together toward a Great Indonesia. We will stretch sturdy sails.

20) Kita akan hadapi semua badai dan gelombang samudera dengan kekuatan kita sendiri.

We will face storms and ocean waves using our own power.

We understand one domain, politics, in terms of a very different domain of experience, navigation. The texts show that Indonesian citizens are sailors who sailed against the waves (example 18). Example 19 expresses that Widodo is the captain of the ship and he sails together with his people. Finally, similar to the domain of journeys, example (20) conveys Indonesian destination, that is "Indonesia Raya" or as translated by Evanston (2014) "Great Indonesia". As Crystal (1987) suggests, the way the speaker uses language gives information about the type of context in which they are communicating. In this sense, The analysis of the source these navigation metaphors appear powerfully because they are in line with one of Widodo's strategies for Indonesian future, that is promoting maritime life. domains in Widodo's addresses shows that we find many conceptual metaphors. A metaphor has a learning power because it facilitates the understanding of messages by converting abstract notions into 
concrete ones (G. Lakoff, 1980; Cuenca \& Hilferty, 1999). The speeches contain several source domains, those are: unity, war, journey, human characteristics and navigation. Those concepts are more concrete to the public's experience, which help them understand a more abstract concept, politics. As a result, the use of metaphors in speeches is believed to be one powerful strategy to convey political messages and win the heart of the public.

\section{Conclusion}

The speeches contain metaphors that have distinct source domains, those are: unity, wars, journeys, human characteristics and navigation. By using more concrete domains to public's experience,
Widodo calls people to unite as one nation to survive, protect and struggle for Indonesian future. For these reasons, the speeches use more positive metaphors of "unity" rather than metaphors of "a battle or competition". Furthermore, the texts conceptualize Indonesian political life as a journey and navigation. By using these domains, the speeches give the audience a sense of progress. The maritime metaphors are abundant which are in line with one of Widodo's missions to strengthen Indonesian maritime life. Metaphors are also exploited by converting abstract notions into concrete ones related to human body. In sum, many metaphors in these speeches conceptualize the abstract domain of politics into something related to human basic experience.

\section{References}

. (N.D.) British Political Speech: Why rethoric? Retrieved January 2016 from http://www.britishpoliticalspeech.org/why-rhetoric.htm

Crystal, D. (1987). Encyclopedia of language. Cambridge: Cambridge University Press.

Escudero, M. P. G. (2011) Barack Obama's inaugural address: Metaphor and values as captivating strategies to celebrate a presidency.

Pragmalingiüística 19 (2011) 44-55. Retrieved January 2016 from http://www.revistas.uca.es

Evanston, S. S. P. (2014) When first impressions matter: Jokowi's inaugural speech. The Jakarta Post. Retrieved July 2015 from

http://www.thejakartapost.com/news/2014/10/29/when-first-impressionsmatter-jokowi-s-inaugural-speech.html

$\mathrm{Hu}, \mathrm{X}$. (2010). A study on conceptual metaphors in presidential inaugural speeches. Unpublished research paper. Kristianstad University. Retrieved January 2016 from http://www.divaportal.se/smash/get/diva2:397472/FULLTEXT01.pdf

Kovecses, Z. (2010). Metaphor: A practical introduction. $2^{\text {nd }}$ ed. Oxford: Oxford University Press.

Lakoff, G. and Johnson, M. (1980). Metaphors we live by. Chicago: University of Chicago Press. 
Lakoff, G. (1992). The contemporary theory of metaphor. In Ortony, Andrew. 1993. Metaphor and Thought. Cambridge: Cambridge University Press.

Pasaribu, T. A. (2013). A cognitive linguistic analysis of Indonesian love metaphors. Seminar Internasional. Yogyakarta: UGM

Procter, P. (2008) Cambridge Advanced Learners' Dictionary. $3^{\text {rd }}$ ed. Cambridge: Cambridge University Press.

Wahab, Abdul. (1991). kesemestaan metafora Jawa. dalam isu Linguistik, Pengajaran Bahasa dan Sastra. Isu Linguistik Pengajaran Bahasa dan Sastra. Surabaya: Airlangga University Press.

Widiana, Y. \& Yustisiana R. A. (2015) Metaphors and arguments to semantic political metaphors in Indonesian mass media and its persuasive effect toward readers. Celt, Volume 15, Number 2, December 2015, pp. 205-221

Wilson, D. (1994) Language and understanding. Oxford: Oxford University Press. 